\title{
Oxidation of pharmaceuticals by chlorine dioxide in biologically treated wastewater
}

\author{
Hey, G.; Grabic, R.; Ledin, A.; la Cour Jansen, J.; Andersen, H.R.
}

Published in:

Chemical Engineering Journal

Link to article, DOI:

10.1016/j.cej.2012.01.093

Publication date:

2012

Link back to DTU Orbit

Citation (APA):

Hey, G., Grabic, R., Ledin, A., la Cour Jansen, J., \& Andersen, H. R. (2012). Oxidation of pharmaceuticals by chlorine dioxide in biologically treated wastewater. Chemical Engineering Journal, 185-186, 236-242. https://doi.org/10.1016/j.cej.2012.01.093

\section{General rights}

Copyright and moral rights for the publications made accessible in the public portal are retained by the authors and/or other copyright owners and it is a condition of accessing publications that users recognise and abide by the legal requirements associated with these rights.

- Users may download and print one copy of any publication from the public portal for the purpose of private study or research.

- You may not further distribute the material or use it for any profit-making activity or commercial gain

- You may freely distribute the URL identifying the publication in the public portal 


\title{
Oxidation of pharmaceuticals by chlorine dioxide in biologically treated wastewater
}

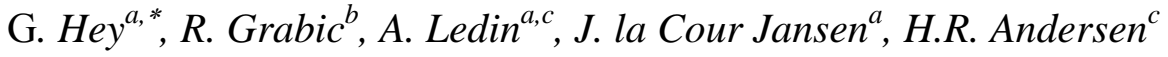

${ }^{a}$ Water and Environmental Engineering, Department of Chemical Engineering, Lund University, P.O. Box 124, SE-221 00 Lund, Sweden

${ }^{\mathrm{b}}$ Department of Chemistry, Umeå University, SE-901 87 Umeå, Sweden

${ }^{\mathrm{c}}$ Department of Environmental Engineering, Technical University of Denmark, Miljøvej, Building 113, DK-2800 Kongens Lyngby, Denmark

*Corresponding author: Gerly Hey, Phone: +46 46222 8998; fax: +46 462224526

Email: gerly.moradas@chemeng.lth.se 


\begin{abstract}
Biologically treated wastewater spiked with a mixture of 56 active pharmaceutical ingredients (APIs) was treated with $0-20 \mathrm{mg} / \mathrm{L}$ chlorine dioxide $\left(\mathrm{ClO}_{2}\right)$ solution in laboratory-scale experiments. Wastewater effluents were collected from two wastewater treatment plants in Sweden, one with extended nitrogen removal (low COD) and one without (high COD). About one third of the tested APIs resisted degradation even at the highest $\mathrm{ClO}_{2}$ dose $(20 \mathrm{mg} / \mathrm{L})$, while others were reduced by more than $90 \%$ at the lowest $\mathrm{ClO}_{2}$ level $(0.5 \mathrm{mg} / \mathrm{L})$. In the low COD effluent, more than half of the APIs were oxidized at $5 \mathrm{mg} / \mathrm{L} \mathrm{ClO}$, while in high COD effluent a significant increase in API oxidation was observed after treatment with $8 \mathrm{mg} / \mathrm{L} \mathrm{ClO}$. This study illustrates the successful degradation of several APIs during treatment of wastewater effluents with chlorine dioxide.
\end{abstract}

Keywords: Pharmaceuticals; Chlorine dioxide; Wastewater effluent

\title{
1. Introduction
}

One of the pressing problems in wastewater treatment plants (WWTPs) is the inability of conventional methods to completely remove active pharmaceutical ingredients (APIs) due to their high resistance to biodegradation and/or limited biological activity, especially in cold climates such as that in Sweden [1,2]. The extensive usage and hence release of traces of many pharmaceuticals in wastewater effluents may lead to surface and groundwater contamination compromising the aquatic ecosystem and the environment $[3,4]$.

Where biological treatment is not sufficient, improvement in WWTPs can be achieved by an additional chemical oxidation step to remove potential pollutants that cannot be degraded biologically $[5,6,7,8]$. Among the chemical oxidants applied in water treatment reported in the literature, chlorine dioxide is one that merits further investigation regarding its potential to remove APIs in wastewater. As in the case of ozonation, the application of chlorine dioxide to treat drinking water, surface water and wastewater effluents has shown promising results for the removal of pharmaceuticals. The non-steroidal anti-inflammatory drug diclofenac, reported as one of the most frequently detected compounds in water at concentrations up to the $\mu \mathrm{g} / \mathrm{L}$ level [9], is among the pharmaceuticals completely degraded during drinking 
and surface water treatment at the lowest $\mathrm{ClO}_{2}$ dose applied [10]. In wastewater effluents, steroid estrogens and industrial estrogenic chemicals, as well as personal care products, were removed by low doses of $\mathrm{ClO}_{2}$ between 1.25 and $3.75 \mathrm{mg} / \mathrm{L}$, and the removal of estrogenic potency was observed at the same time [11]. The removal of several antibiotics found in water has also demonstrated the ability of $\mathrm{ClO}_{2}$ as an oxidant $[12,13]$.

When $\mathrm{ClO}_{2}$ was used for selective oxidation of organic micropollutants in other investigations on biologically treated wastewater, it was found that smaller doses, e.g. up to $4 \mathrm{mg} / \mathrm{L}$ (depending on the concentrations tested and the matrix) were consumed in less than a minute through reactions with the soluble components in the water, while still completely removing many of the reactive micropollutants. This fast consumption of the oxidant in wastewater has been observed in previous studies by Andersen [11], Hey et al. [14], Lee and von Gunten [6] and Andersen et al. [15]. Based on $\mathrm{ClO}_{2}$ reactivity in wastewater effluents, it has been suggested that $\mathrm{ClO}_{2}$ could be used as an alternative to ozone for the removal of micropollutants. It is easy to introduce a $\mathrm{ClO}_{2}$ dosing step in a WWTP since $\mathrm{ClO}_{2}$ is produced as a solution in water by mixing aqueous solutions of the reactants in a simple reactor; furthermore, the $\mathrm{ClO}_{2}$ stock solution is semi-storable. This is much simpler than treatment with ozone, which requires on-site delivery of dry oxygen and considerable electric power to run an expensive and complicated ozone generator which produces an ozone gas mixture with less than $20 \%$ ozone yield. Following the generation of ozone, the gas must be transferred to the water using a gas contact reactor, usually with 5-20 min hydraulic retention time $[5,7,16]$.

When $\mathrm{ClO}_{2}$ is used for oxidation of water with low NOM (natural organic matter), most of the $\mathrm{ClO}_{2}$ is reduced to chlorite by reactions with the organic matter. Chlorate is also formed as a by-product, but at a much lower concentration than chlorite [17, 18,19]. According to Korn [18] and Lee [19], the formation of chlorite and chlorate accounts for about $70 \%$ and $10 \%$, respectively, of the chlorine dioxide applied. In drinking water with low NOM, chlorite reacts slowly with organic matter and is reduced to chloride, while in wastewater, significantly more NOM is available to reduce the chlorite. Toxicity derived from chlorite residuals after treatment may be problematic depending on the concentration and degradation rate [20]. $\mathrm{ClO}_{2}$ differs from chlorine in that it produces very little chloro-organic by-products $[11,15,21]$. 
The formation of undesirable by-products can be controlled by minimizing the dose of $\mathrm{ClO}_{2}$ and applying post-treatment using, for example, ferrous iron $\left(\mathrm{Fe}^{2+}\right)$ or sulfite $\left(\mathrm{SO}_{3}{ }^{2-}\right)$, which reduces $\mathrm{ClO}_{2}$ and chlorite residuals to chloride [22,23]. The removal of $\mathrm{ClO}_{2}$ and chlorite residuals allows higher levels of $\mathrm{ClO}_{2}$ to be used for treatment providing effective micropollutant removal.

In this study, the removal of 56 different APIs in biologically treated wastewater was investigated in both low- and high-COD effluents using different doses of chlorine dioxide. The APIs were chosen to represent different classes of pharmaceuticals commonly sold and used in Sweden, which will most likely end up in WWTP effluents due to their low sorption to sludge [24]. The effectiveness of the treatment was evaluated by monitoring the oxidant consumption and the amount of APIs oxidized. Oxidation by-products were not evaluated in this study as the aim was to determine the most suitable oxidant dose and identify which APIs can be removed. Once the relevant dose has been determined, attention can be turned towards investigating the $\mathrm{ClO}_{2}$ by-products.

\section{Materials and methods}

\subsection{Chemicals}

All pharmaceutical reference standards were purchased as solids of analytical grade (>98\%) from different suppliers. All APIs investigated are listed in Supplementary Information Table S1. Methanol and acetonitrile were of LC/MS grade (Merck, Darmstadt, Germany). Ultrapure water was prepared from deionized water using a Milli-Q Gradient system (Millipore, Billerica, MA), equipped with a UV radiation source. A stock solution of APIs was prepared in methanol at concentration of about $100 \mathrm{mg} / \mathrm{L}$. Solutions for spiking and analysis were prepared by precise dilution of the stock solution. Chlorine dioxide was synthesized by adding equal volumes $(25 \mathrm{~mL}$ each) of $9 \% \mathrm{HCl}$ (Merck, Darmstadt, Germany) and 7.5\% $\mathrm{NaClO}_{2}$ (Sigma Aldrich, Steinheim, Germany) to $400 \mathrm{~mL}$ deionized water. The solution was allowed to react in the dark for at least 10 hours and then diluted to $1000 \mathrm{~mL}$ with water. This resulted in an approximately $1 \mathrm{~g} / \mathrm{L} \mathrm{ClO}_{2}$ stock solution.

\subsection{Analytical methods}

The concentration of residual $\mathrm{ClO}_{2}$ was quantified by reaction with DPD (N,Ndiethyl-p-phenylenediamine) using an Allcon spectrophotometer (Alldos GmbH, 
Germany) with a built-in calibration line for $\mathrm{ClO}_{2}$. The analysis of $\mathrm{ClO}_{2}$ with DPD was performed according to the manufacturer's instructions.

For the analysis of the APIs, samples of $100 \mathrm{~mL}$ treated effluent were filtered using a $0.45 \mu \mathrm{m}$ membrane filter (Millipore, Ireland) then acidified to $\mathrm{pH} 3$ using sulfuric acid. Five ng of ${ }^{13} \mathrm{C}$ - and ${ }^{2} \mathrm{H}$-labelled APIs was added as internal standards, to each sample (see Supplementary Table 1 for the complete list) before solid-phase extraction using Oasis HLB columns (200 mg, Waters). LC/MS/MS analysis of the extracts was carried out using a triple-stage quadrupole mass spectrometer (MS/MS TSQ Quantum Ultra EMR) coupled to an Accela LC pump (both from Thermo Fisher Scientific, San Jose, CA, USA) and a PAL HTC autosampler (CTC Analytics AG, Zwingen, Switzerland) with a Hypersil GOLD aQ ${ }^{\mathrm{TM}}$ column (50 mm x $2.1 \mathrm{~mm}$ ID x 5 $\mu \mathrm{m}$ particles). Both heated electrospray and atmospheric pressure photoionization were used in positive and negative ion modes for the ionization of target compounds. Two MS/MS transitions were measured for each API. Samples were quantified using isotope dilution or internal standard methods. Six points calibration curve corresponding to concentration ranges 10 to $2500 \mathrm{ng} / \mathrm{L}$ were measured before, in the middle and at the end of sample analysis sequence to monitor response factor stability. Recoveries and the relative standard deviation of triplicate analyses of effluent from the Sjölunda WWTP spiked at $1 \mu \mathrm{g} / \mathrm{L}$ are given in Supplementary Information Table S2. Maximum difference between results at quantification and qualification mass transition was set to $30 \%$ as criterion for positive identification of the analyte. The same method is used by Hörsing et al. [24] and Grabic et al. (unpublished results) [25].

\subsection{Experimental setup}

\subsubsection{Wastewater effluents}

Wastewater effluents were collected after secondary treatment from two WWTPs in southern Sweden. Effluent 1 was collected from Källby WWTP after the activated sludge system which is operated with extended nitrogen removal.

Effluent 2 was obtained from Sjölunda WWTP after a high loaded activated sludge process before nitrogen removal. This wastewater is typical of that in many Swedish WWTPs which are operated without nitrogen removal due to their location in the northern part of the country where the climate is colder. Sjölunda also employs full nitrogen removal but using a biofilm system after a highly loaded activated sludge 
plant. Nitrification is achieved in trickling filters and denitrification in moving bed biofilm reactors with the addition of external carbon.

Table 1 gives the characteristics of the effluents. The effluents were analyzed using standard Swedish methods for total suspended solids (SS-EN 872:2005), total P (SS-EN ISO 6878:2005) and total N (SS-EN ISO 11905-1), while COD was determined with the Dr. Lange LCK 114 kit. The effluents were classified as low COD (Effluent 1) or high COD effluent (Effluent 2) based on their COD levels.

Table 1

Effluent characteristics

\begin{tabular}{lccccc}
\hline & $\mathrm{pH}$ & $\begin{array}{c}\mathrm{COD} \\
(\mathrm{mg} / \mathrm{L})\end{array}$ & $\begin{array}{c}\text { TSS } \\
(\mathrm{mg} / \mathrm{L})\end{array}$ & $\begin{array}{c}\text { Total P } \\
(\mathrm{mg} / \mathrm{L})\end{array}$ & $\begin{array}{c}\text { Total N } \\
(\mathrm{mg} / \mathrm{L})\end{array}$ \\
\hline Effluent 1 (Källby) & 6.8 & 35 & 5 & 0.26 & 7.5 \\
Effluent 2 (Sjölunda) & 7.2 & 55 & 8 & 0.28 & 8.0 \\
\hline
\end{tabular}

\subsubsection{Oxidation experiments}

Effluent samples of $150 \mathrm{~mL}$ each were prepared in Schott Duran ${ }^{\circledR}$ bottles and spiked with mixed APIs to a final concentration of approx. $1 \mu \mathrm{g} / \mathrm{L} . \mathrm{ClO}_{2}$ was added to duplicate samples at concentrations ranging from 0-20 mg/L. All samples were stored in the dark and allowed to react overnight (approx. $18 \mathrm{~h}$ ) at room temperature, after which the $\mathrm{pH}$ and oxidant concentration in the samples were measured. Residual oxidants were removed by the addition of $50 \mathrm{mg} / \mathrm{L}$ sodium sulfite.

\section{Results and discussion}

Table 2 lists the APIs investigated, including information on the class of drug, arranged according to the ease with which they were oxidized by $\mathrm{ClO}_{2}$ (based on Effluent 1).

No further $\mathrm{pH}$ adjustments were made during the entire experiment. The $\mathrm{pH}$ of the samples did not change significantly after treatment, even with the highest oxidant dose of $20 \mathrm{mg} / \mathrm{L}$, where the sample remained slightly acidic $(\sim \mathrm{pH} \quad 6.2-6.5)$. This slight decrease in $\mathrm{pH}$ is expected since the stock solutions of $\mathrm{ClO}_{2}$ contain some residual $\mathrm{HCl}$ from the synthesis. 
Table 2

Name and chemical structure of the APIs investigated (www.fass.se). The therapeutic class, and in the case of the easily and moderately oxidizable APIs the reactive functional group are given in brackets.

$\begin{aligned} & \text { Buprenorphine } \\ & \text { (narcotic analgesic; } \\ & \text { phenol) }\end{aligned}$
$\begin{aligned} & \text { Clindamycine } \\ & \text { (antibiotics; tertiary } \\ & \text { amine) }\end{aligned}$ antibiotic;
tertiary amine)

\section{Moderately oxidized (2.5-5 mg/ $\left.\mathrm{L} \mathrm{ClO}_{2}\right)$}

Alfuzosin

( $\alpha$-blocker; tertiary amine)<smiles>COc1cc2nc(N(C)CCCNC(=O)C3CCCO3)nc(N)c2cc1OC</smiles>

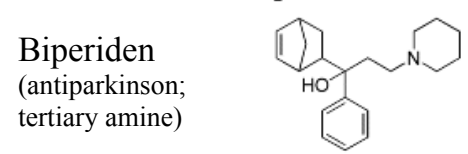

tertiary amine)

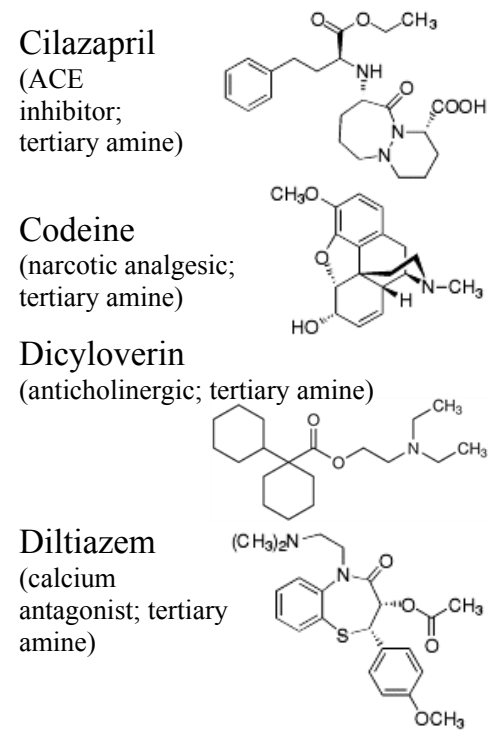

Diphenhydramine

(anxiolytic; tertiary amine)
Fexofenadine

(antihistamine; tertiary amine)

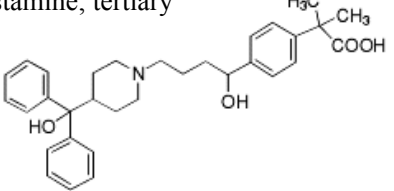

Hydroxyzine

(antihistamine; tertiary amine)

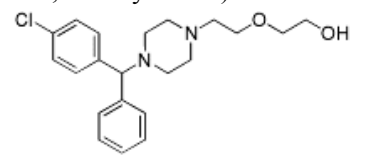

Mianserin

(antidepressant; tertiary amine)

Mirtazapine (antidepressant; tertiary amine)

Orphenadrine (anticholinergic; tertiary amine)

Paroxetine (antidepressant; secondary amine, cyclic)

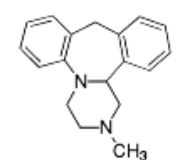

Sotalol

( $\beta$-locker; sulfonamide)

Risperidone

(antipsychotic; tertiary amine)

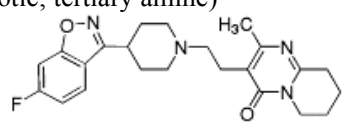

Sulfamethoxazole (antibiotic; aniline)

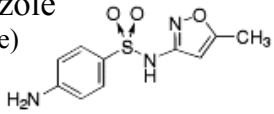

Tramadol

(narcotic analgesic; tertiary amine)
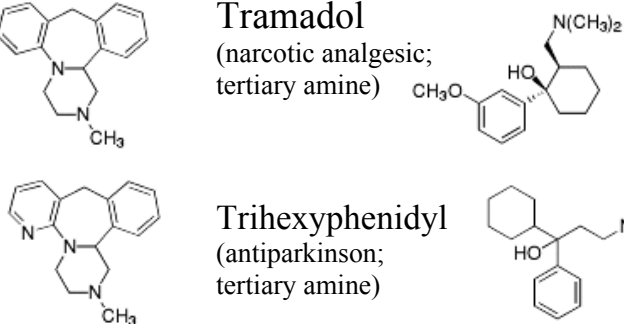

Trihexyphenidyl (antiparkinson; tertiary amine)

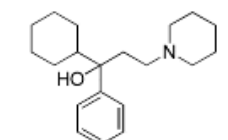

Venlafaxine (antidepressant, tertiary amine)

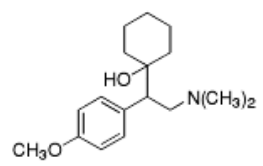

Zolpidem

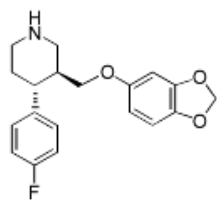

(sedative hypnotic; tertiary amine)

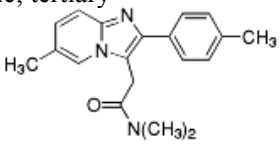


Table 2. Continued.

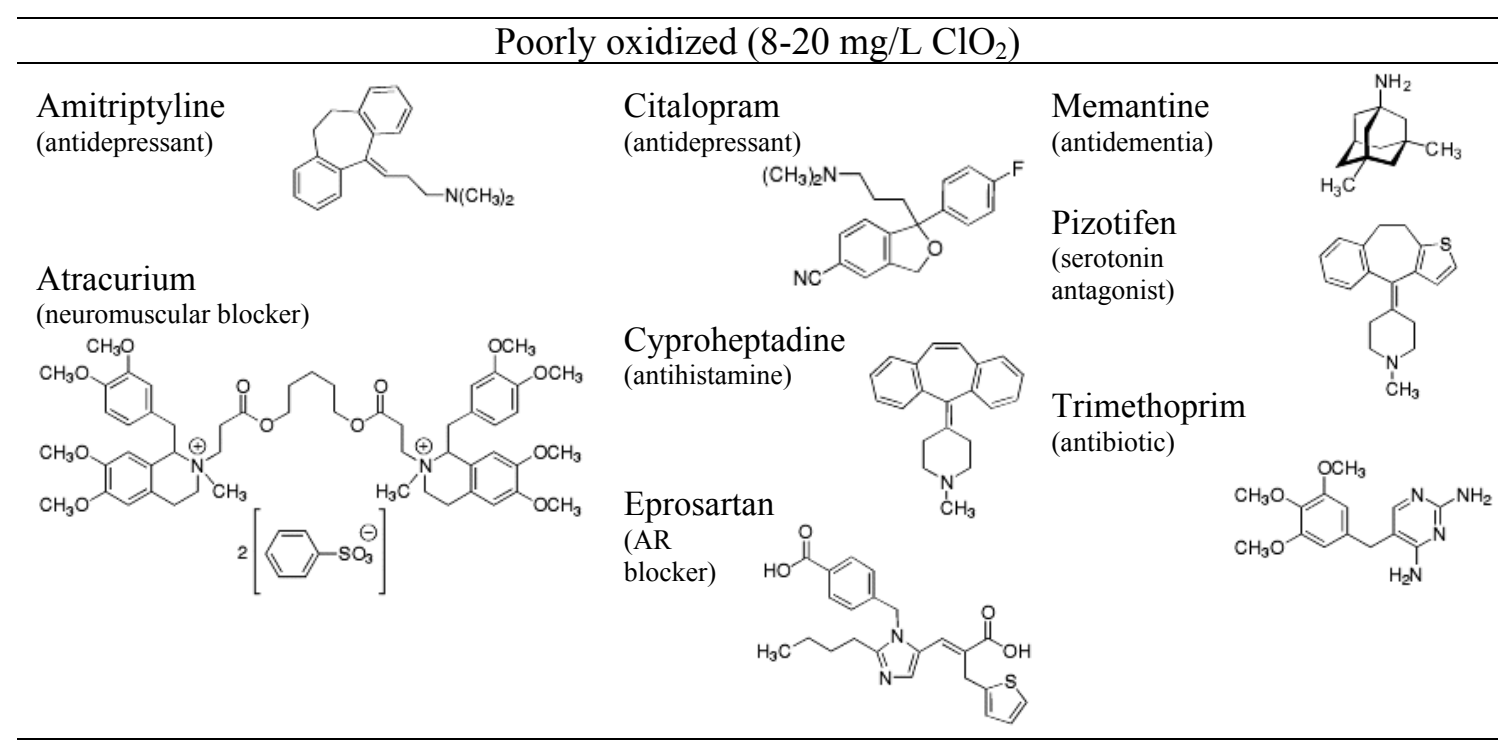

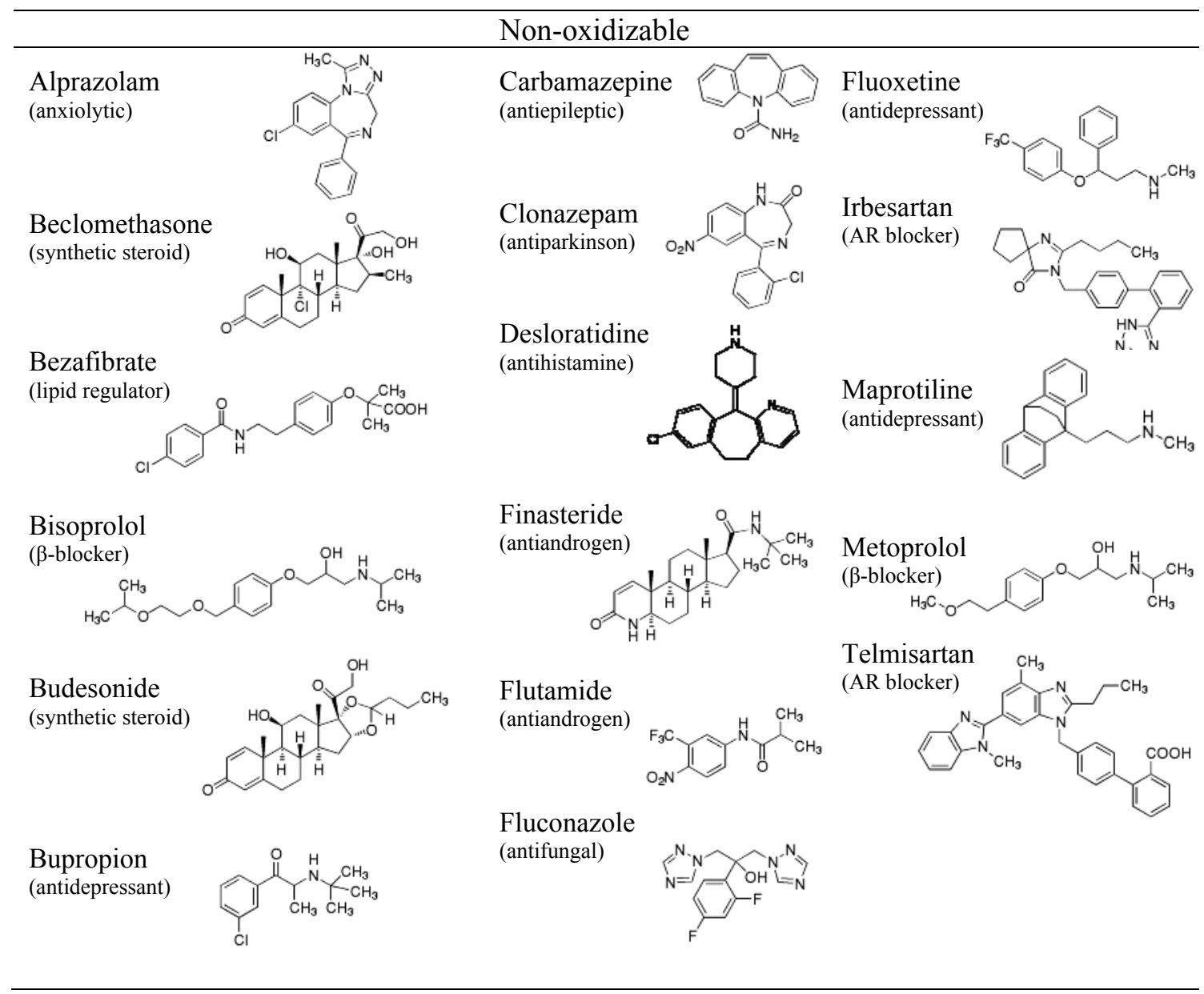

Figure 1 shows the residual concentration of $\mathrm{ClO}_{2}$ in the two effluents spiked with APIs as a function of the initial $\mathrm{ClO}_{2}$ dose. It can be seen that the high COD 
effluent consumed more oxidant than the low COD effluent, especially when the dose was $8 \mathrm{mg} / \mathrm{L} \mathrm{ClO}_{2}$ and above.

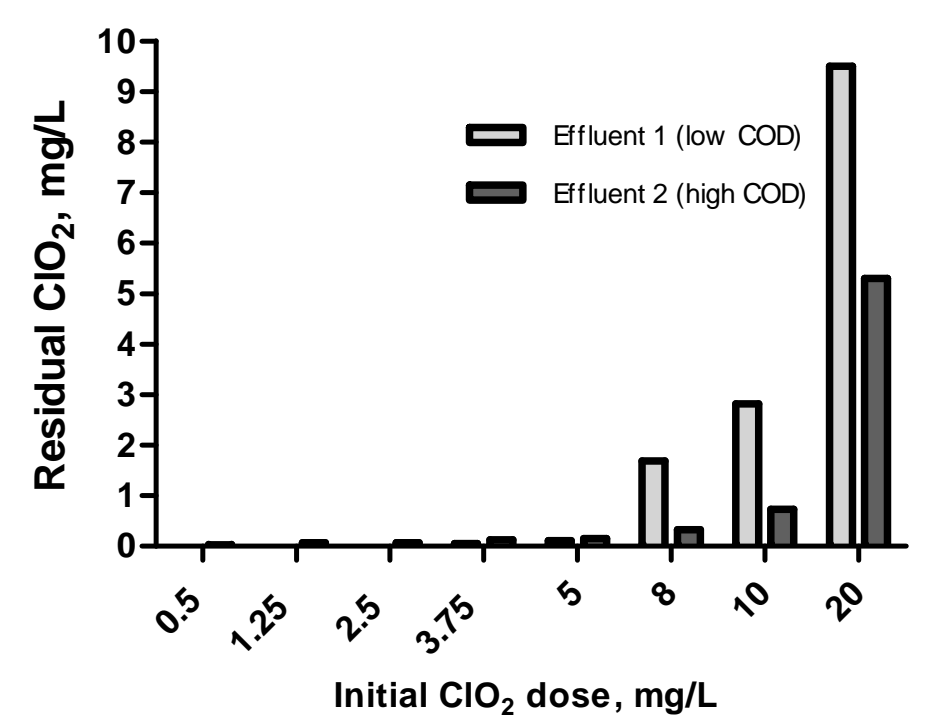

Figure 1. Residual concentration of $\mathrm{ClO} 2$ in the 2 effluents after treatment with different doses of the oxidant.

Table 3 gives the number of APIs that can be effectively oxidized (i.e. by more than $90 \%$ ) at each $\mathrm{ClO}_{2}$ dose in both effluents. It can be seen that a dose of $8 \mathrm{mg} / \mathrm{L}$ $\mathrm{ClO}_{2}$ to Effluent 1 was able to oxidize 38 of 56 APIs, and that only 1 more API was oxidized when the dose was increased to $20 \mathrm{mg} / \mathrm{L}$. In Effluent 2, 33 APIs were oxidized with a dose of $8 \mathrm{mg} / \mathrm{L} \mathrm{ClO}$, and increasing the $\mathrm{ClO}_{2}$ dose to $20 \mathrm{mg} / \mathrm{L}$ oxidized further 4 APIs. The remaining APIs (about one third) could not be degraded effectively (at least 90\%) with a dose of $20 \mathrm{mg} / \mathrm{L} \mathrm{ClO}_{2}$.

Only few APIs were oxidized by more than $90 \%$ at the lowest dose of $\mathrm{ClO}_{2}(0.5$ $\mathrm{mg} / \mathrm{L})$, while high oxidative degradation was observed with higher doses $(8-20 \mathrm{mg} / \mathrm{L})$. The degree to which each API was oxidized at different $\mathrm{ClO}_{2}$ doses is shown in Figure $2 \mathrm{~A}$ and $2 \mathrm{~B}$ for Effluents 1 and 2, respectively. The vertical lines divide the APIs into easily, moderately, poorly (based on the $\mathrm{ClO}_{2}$ dose required to achieve 90-100\% degradation) and non-oxidizable APIs (less than 90\% degradation with $20 \mathrm{mg} / \mathrm{L}$ $\mathrm{ClO}_{2}$ ).

As shown for Effluent 1 (Figure 2A and Table 2), 11 of the APIs from 8 different therapeutic classes could be oxidized by more than $90 \%$ with $0.5-1.25 \mathrm{mg} / \mathrm{L} \mathrm{ClO}$. These include all 3 hormones, 2 antibiotics, 1 antihistamine, and 1 narcotic analgesic, 
as well as the antiplatelet, antidiabetic, antiphlogistic and narcotic antagonist compounds. The common reactive and electron-rich functional groups in these APIs are aniline in diclofenac, phenol in hormones, buprenorphine, and naloxone, and tertiary amines in promethazine, clindamycine, dipyridamole, repaglinide and ciprofloxacin. The high reactivity of $\mathrm{ClO}_{2}$ with aniline, phenolic and tertiary amine functional groups has been reported in a number of studies $[6,10,26]$. The reactivity of $\mathrm{ClO}_{2}$ with the piperazine ring of the antibiotic ciprofloxacin has also been reported by Wang et al. [13]. Similarly, Navalon et al. [12] also showed high reactivity of ciprofloxacin with $\mathrm{ClO}_{2}$ in both surface water and wastewater effluent.

\section{Table 3}

The number of APIs tested (of a total of 56) that could be effectively oxidized (at least 90\%) at each $\mathrm{ClO}_{2}$ dose

\begin{tabular}{|ccc|}
\hline & \multicolumn{2}{c|}{ No. of APIs oxidized by $>90 \%$} \\
$\mathrm{ClO}_{2}$ dose, $\mathrm{mg} / \mathrm{l}$ & $($ Effluent 1$)$ & (Effluent 2$)$ \\
\hline 0.5 & 4 & 0 \\
1.25 & 11 & 4 \\
2.5 & 15 & 8 \\
3.75 & 24 & 12 \\
5 & 31 & 18 \\
8 & 38 & 33 \\
10 & 38 & 36 \\
20 & 39 & 37 \\
\hline
\end{tabular}

APIs requiring doses of 2.5-5 $\mathrm{mg} / \mathrm{L} \mathrm{ClO}_{2}$ for oxidation are considered to be moderately oxidizable (Table 2). Most of the APIs from 13 of the different therapeutic classes belong to this category including 4 antidepressants, 2 antihistamines, 2 antiparkinson drugs, 2 narcotic analgesics, 2 anticholinergics, 1 antibiotic, 1 beta blocker, 1 sedative-hypnotic, 1 anxiolytic, and the representative compound from different classes, namely angiotensin converting enzyme (ACE) inhibitor, alpha blocker, antipsychotic and calcium antagonist. The most common functional group in this category of moderately oxidizable APIs is the tertiary amino group, which is also found in the structures of easily oxidizable APIs. However, despite belonging to the same therapeutic class, the behavior of the APIs differed significantly, depending largely on the reactivity of electron-rich functional groups. The removal of pharmaceuticals at fairly low oxidant doses $\left(1.25-3.75 \mathrm{mg} / \mathrm{L} \mathrm{ClO}_{2}\right)$ has also been 
observed in previous studies on surface and drinking water [10] and in wastewater effluents $[6,11]$.
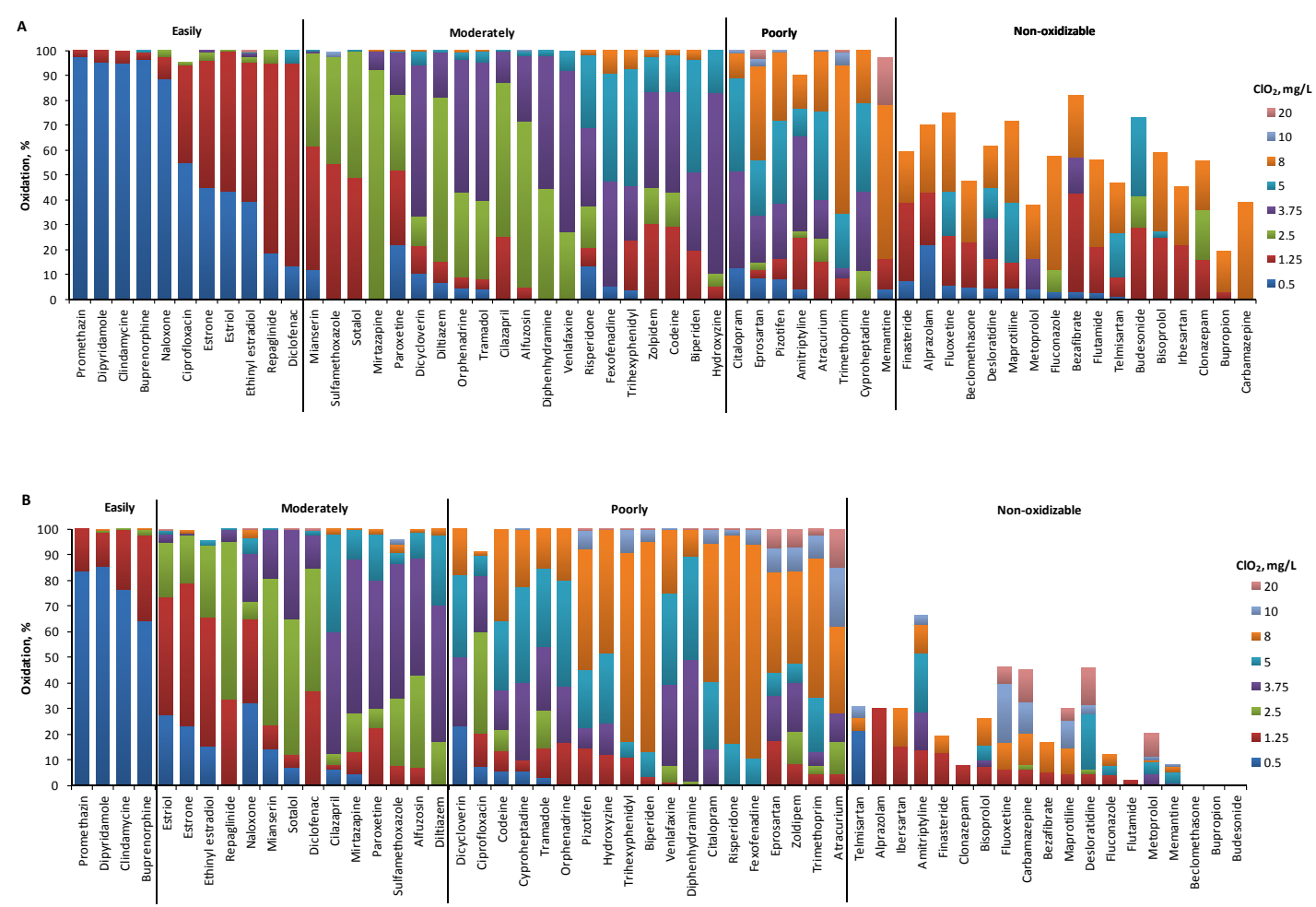

Figure 2. Fraction of APIs oxidized in Effluent 1 (A) and Effluent 2 (B) at different $\mathrm{ClO}_{2}$ doses. The vertical lines divide the APIs into groups according to their ease of oxidation.

The resistance of poorly and non-oxidizable APIs to oxidation by $\mathrm{ClO}_{2}$ could be attributed to the presence of the electron-withdrawing functional groups such as the chloro (in clonazepam, bupropion, desloratidine, alprazolam, bezafibrate, and beclomethasone), fluoro (in citalopram, flutamide, fluoxetin, fluconazole), nitro (in flutamide and clonazepam), olefin or $\mathrm{C}=\mathrm{C}$ double bonds (in eprosartan and amitriptyline), amide carbonyl (in bezafibrate and finasteride) and keto group (in bupropion, beclomethasone and budesonide) [7,26,27,28,29]. The secondary aminecontaining beta blockers, metoprolol and bisoprolol are also considered less susceptible to $\mathrm{ClO}_{2}$ oxidation. Lee and von Gunten [6] reported the poor transformation of the beta blocker atenolol which has a secondary amine functional group. However, the oxidizability of the beta blocker sotalol can be explained by the presence of the $\mathrm{ClO}_{2}$ reactive sulfonamide functional group in its structure. The same 
degree of API oxidation can be achieved in the high COD effluent (2) as in the low COD effluent (1), but higher $\mathrm{ClO}_{2}$ doses are required. This is due to consumption of the $\mathrm{ClO}_{2}$ competitively with the APIs by other organic components in the wastewater [6]. In addition, the presence of inorganic components in the wastewater also consumes some of the oxidant and this could affect the removal of the target micropollutants [6].

The results of this study showed that about 20 APIs cannot be oxidized effectively, even at the highest dose investigated $(20 \mathrm{mg} / \mathrm{L} \mathrm{ClO})_{2}$, suggesting low reactivity between these APIs and $\mathrm{ClO}_{2}$. In Effluent 1, 13 of these APIs (alprazolam, finasteride, fluoxetine, beclomethasone, desloratadine, maprotiline, fluconazole, bezafibrate, flutamide, telmisartan, budesonide, bisoprolol, and clonazepam) were oxidized by $50-80 \%$, while the remaining 4 APIs metoprolol, irbesartan, bupropion, and carbamazepine were degraded less (20-40\%). On the other hand, in Effluent 2, most of these APIs were oxidized by less than 50\%, while 3 APIs (the synthetic steroids beclomethasone and budesonide, and the antidepressant bupropion) did not show any degradation at all. Bezafibrate and carbamazepine have been shown in previous investigations to be recalcitrant to $\mathrm{ClO}_{2}$ oxidation during water and wastewater treatment $[10,6,28]$. As mentioned above, the presence of electronwithdrawing functional groups results in low reactivity of some APIs to $\mathrm{ClO}_{2}$ oxidation, and thus a much higher dose of $\mathrm{ClO}_{2}$ would be needed for oxidation.

APIs such as diclofenac, sulfamethoxazole and estrogens have been found to be oxidized by more than $90 \%$ during ozonation of municipal wastewater effluents at $\mathrm{O}_{3}$ doses of $\geq 2 \mathrm{mg} / \mathrm{L}$, while a much higher $\mathrm{O}_{3}$ dose was required for the effective removal of bezafibrate [30]. Ternes et al. [7] also found significant removal (>90\%) of sulfamethoxazole, diclofenac, carbamazepine, and sotalol during treatment of municipal sewage effluent with $5 \mathrm{mg} / \mathrm{L} \mathrm{O}_{3}$, while a higher $\mathrm{O}_{3}$ dose of $10-15 \mathrm{mg} / \mathrm{L}$ was required to effectively remove the beta blocker metoprolol, which also exhibits low reactivity to $\mathrm{ClO}_{2}$. In the present study, $\mathrm{ClO}_{2}$ was able to oxidize several APIs effectively at doses comparable to those of ozone. The reactivity of carbamazepine was very different since it could be removed by low ozone doses, while it is almost completely resistant to $\mathrm{ClO}_{2}$.

The oxidation of APIs by $\mathrm{ClO}_{2}$ is comparable to oxidation by molecular ozone as both are selective oxidants and are capable of transforming organic micropollutants 
based on the reactivity of the structure and the characteristics of the water matrix. These chemical oxidants react with electron-rich functional groups such as phenolic and amino groups, which can be found in the structures of most of the APIs investigated $[6,10,31,32,33]$. However, the reaction between $\mathrm{ClO}_{2}$ and some APIs was much slower than ozonation, even with the same reactive functional group. Therefore, the usefulness of $\mathrm{ClO}_{2}$ end-of-pipe treatment of WWTP effluents will depend on whether the micropollutants deemed to be critical for the receiving water are sensitive to $\mathrm{ClO}_{2}$. Running costs must also be considered since $\mathrm{ClO}_{2}$ is slightly more expensive to produce than ozone, while it is far simpler and less expensive to build both the generator and reaction chamber for $\mathrm{ClO}_{2}$ treatment. The treatment perspective then is mainly to use $\mathrm{ClO}_{2}$-treatment for small scale WWTP $(<2,000$ person equivalent $)$ effluents or where treatment is required only for a limited time.

Two of the APIs investigated here may be of considerable concern regarding the discharge of wastewater effluents into surface water. Both ethinyl estradiol, a pharmaceutical with a high endocrine-disrupting ability [34], and diclofenac, identified as a contaminant that causes direct toxic effects in the environment $[35,36]$, were found to be very sensitive to $\mathrm{ClO}_{2}$ oxidation. However, if other less reactive APIs, e.g. bezafibrate or carbamazepine, were found to be of concern regarding aquatic life in the receiving water body of the WWTP effluent, $\mathrm{ClO}_{2}$ treatment would not be a suitable treatment option.

\section{Conclusions}

The results of this study show that $\mathrm{ClO}_{2}$ can be used to treat wastewater effluents to oxidize various APIs belonging to different therapeutic classes. However, there was considerable variation in the reactivity of the investigated APIs to $\mathrm{ClO}_{2}$. The degree of oxidation was found to be dependent on the type of wastewater; API removal is better from the low COD wastewater from the plant with extended nitrogen removal, than the one without (high COD wastewater), at the same oxidant dose. In addition, the reactivity of the APIs depends on the reactive functional group present. APIs with electron-withdrawing functional groups appear to be more resistant to $\mathrm{ClO}_{2}$ oxidation.

$\mathrm{ClO}_{2}$ oxidation by-products and toxicity must be investigated before this method can be considered for application in wastewater treatment. The use of $\mathrm{ClO}_{2}$ oxidation 
for the removal of pharmaceuticals may be beneficial in small wastewater treatment plants where ozonation could be too expensive and complicated.

\section{Acknowledgements}

The authors would like to thank the Swedish Foundation for Strategic Environmental Research through the MistraPharma programme for the full financial support of this study.

\section{References}

[1] K. Kimura, H. Hara, Y. Watanabe, Removal of pharmaceutical compounds by submerged membrane bioreactors (MBRs), Desalination 178 (2005) 135-140.

[2] N.M. Vieno, T. Tuhkanen, L. Kronberg, Seasonal variation in the occurrence of pharmaceuticals in effluents from a sewage treatment plant and in the recipient water, Environ. Sci. Technol. 39 (2005) 8220-8226.

[3] K. Fent, A.A. Weston, D. Caminada, Ecotoxicology of human pharmaceuticals, Aquat. Toxicol. 76 (2006) 122-159.

[4] S.A. Snyder, Occurrence, treatment, and toxicological relevance of EDCs and pharmaceuticals in water, Ozone-Sci. Eng. 30 (2008) 65-69.

[5] K.M.S. Hansen, H.R. Andersen, A. Ledin, Ozonation of estrogenic chemicals in biologically treated sewage, Water Sci. Technol. 62 (2010) 649-657.

[6] Y. Lee, U. von Gunten, Oxidative transformation of micropollutants during municipal wastewater treatment: comparison of kinetic aspects of selective (chlorine, chlorine dioxide, ferrate ${ }^{\mathrm{VI}}$, and ozone) and non-selective oxidants (hydroxyl radical), Water Res. 44 (2010) 555-566.

[7] T.A. Ternes, J. Stuber, N. Herrmann, D. McDowell, A. Ried, M. Kampmann, B. Teiser, Ozonation: a tool for removal of pharmaceuticals, contrast media and musk fragrances from wastewater?, Water Res. 37 (2003)1976-1982.

[8] F.J. Benitez, J.L. Acero, F.J. Real, G. Roldan, F. Casas, Comparison of different chemical oxidation treatments for the removal of selected pharmaceuticals in water matrices, Chem. Eng. J. 168 (2011) 1149-1156.

[9] T.A Ternes, Occurrence of drugs in German sewage treatment plants and rivers, Water Res. 32 (1998) 3245-3260.

[10]M.M. Huber, S. Korhonen, T.A. Ternes, U. von Gunten, Oxidation of pharmaceuticals during water treatment with chlorine dioxide, Water Res. 39 (2005) 3607-3617.

[11]H.R. Andersen, Use of $\mathrm{ClO}_{2}$ for removal of estrogenic substances in wastewater, Patent WO2010/023311, 2010 Mar 4.

[12]S. Navalon, M. Alvaro, H. Garcia, Reaction of chlorine dioxide with emergent water pollutants: product study of the reaction of three $\beta$-lactam antibiotics with $\mathrm{ClO}_{2}$, Water Res. 42 (2008) 1935-1942.

[13]P. Wang, Y. He, C. Huang, Oxidation of fluoroquinolone antibiotics and structurally related amines by chlorine dioxide: reaction kinetics, product and pathway evaluation, Water Res. 44 (2010) 5989-5998. 
[14]G. Hey, A. Ledin, J. la Cour Jansen, H.R. Andersen, Removal of pharmaceuticals in biologically treated wastewater by chlorine dioxide or peracetic acid, Environ. Technol. (2011) Online preprint. doi:10.1080/09593330.2011.606282.

[15]H.R. Andersen, M. Lundsbye, H.W. Vedel, E. Eriksson, A. Ledin, Estrogenic personal care products in a greywater reuse system, Water Sci. Technol. 56 (2007) 45-49.

[16]A. Ried, J. Mielcke, A. Wieland, The potential use of ozone in municipal wastewater, Ozone-Sci. Eng. 31 (2009) 415-421.

[17] V. Csordas, B. Bubnis, I. Fabian, G. Gordon, Kinetics and mechanism of catalytic decomposition and oxidation of chlorine dioxide by the hypochlorite ion, Inorg. Chem. 40 (8) (2001) 1833-1836.

[18]C. Korn, R.C. Andrews, M.D. Escobar, Development of chlorine dioxide-related by-product models for drinking water treatment, Water Res. 36 (2002) 330-342.

[19] Y. Lee, H. Kim, U. Lee, Formation of chlorite and chlorate from chlorine dioxide with Han river water, Korean J. Chem. Eng. 21 (3) (2004) 647-653.

[20]D. Gates, G. Zigilio, K. Ozekin, State of the Science of Chlorine Dioxide in Drinking Water, American Water Research Foundation ISBN: 9781605730509 , 2011.

[21]M.M. Huber, Elimination of pharmaceuticals during oxidative treatment of drinking water and wastewater: application of ozone and chlorine dioxide (dissertation). Swiss Federal Institute of Technology Zurich, 2004.

[22]A. Katz and N. Narkis, Removal of chlorine dioxide disinfection by-products by ferrous salts, Water Res. 35 (1) (2001) 101-108.

[23] M.H. Griese, K. Hauser, M. Berkemeier, G. Gordon, Using reducing agents to eliminate chlorine dioxide and chlorite ion residuals in drinking water, J. Am. Water Works Ass. 83 (5) (1991) 56-61.

[24] M. Hörsing, A. Ledin, R. Grabic, J. Fick, M. Tysklind, J. La Cour Jansen, H.R. Andersen, Determination of sorption of seventy-five pharmaceuticals in sewage sludge, Water Res. 45 (2011) 4470-4482.

[25]R. Grabic, J. Fick, R.H. Lindberg, G. Fedorova, M. Tysklind, Multi-residue method for determination of trace levels of 100 pharmaceuticals in environmental samples using liquid chromatography coupled to triple quadrupole mass spectrometry, (unpublished results).

[26] J. Hoigné, H. Bader, Kinetics of reaction of chlorine dioxide $(\mathrm{OClO})$ in water $-\mathrm{i}$. rate constants for inorganic and organic compounds, Water Res. 28 (1) (1994) 4555.

[27]B. Razavi, W. Song, W.J. Cooper, J. Greaves, J. Jeong, Free-Radical-Induced Oxidative and Reductive Degradation of Fibrate Pharmaceuticals: Kinetic Studies and Degradation Mechanisms, J. Phys. Chem. A 113 (2009) 1287-1294.

[28]T. Kosjek, H.R. Andersen, B. Kompare, A. Ledin, E. Heath, Fate of carbamazepine during water treatment, Environ. Sci. Technol. 43 (2009) 62566261.

[29] A.B.C. Alvares, C. Diaper, S.A. Parsons, Partial oxidation by ozone to remove recalcitrance from wastewaters: a review, Environ. Technol. 22 (2010) 409-427.

[30] M.M. Huber, A Göbel., A. Joss, N. Hermann, D. Löffler, C.S. Mcardell, A. Ried, H. Siegrist, T.A. Ternes, U. von Gunten, Oxidation of pharmaceuticals during ozonation of municipal wastewater effluents: a pilot study. Environ. Sci. Technol. 39 (2005) 4290-4299. 
[31] M.O. Buffle, U. von Gunten, Phenols and amine induced $\mathrm{HO}^{\bullet}$ generation during the initial phase of natural water ozonation, Environ. Sci. Technol. 40 (2006) 3057-3063.

[32] V.K. Sharma, Oxidative transformation of environmental pharmaceuticals by $\mathrm{Cl}_{2}$, $\mathrm{ClO}_{2}, \mathrm{O}_{3}$ and $\mathrm{Fe}$ (VI): kinetics assessment, Chemosphere 73 (2008) 1379-1386.

[33]D. Vogna, R. Marotta, A. Napolitano, R. Andreozzi, M. d'Ischia, Advanced oxidation of the pharmaceutical drug diclofenac with $\mathrm{UV} / \mathrm{H}_{2} \mathrm{O}_{2}$ and ozone, Water Res. 38 (2004) 414-422.

[34]A.O. Ifelebuegu, The fate and behaviour of selective endocrine disrupting chemicals in full scale wastewater and sludge treatment unit processes, Int. J. Environ. Sci. Technol. 8 (2011) 245-254.

[35]J.L. Oaks, M. Gilbert, M.Z. Virani, R.T. Watson, C.U. Meteyer, B.A. Rideout, H.L. Shivaprasad, S. Ahmed, M.J.I. Chaudry, M. Arshad, S. Mahmood, A. Ali, A.A. Khan, Diclofenac residues as the cause of vulture population decline in Pakistan, Nature 427 (2004) 630-633.

[36] V. Naidoo, G.E. Swan, Diclofenac toxicity in Gyps vulture is associated with decreased uric acid excretion and not renal portal vasoconstriction, Comp. Biochem. Phys. C. 149 (2009) 269-274.

Web reference

[1] http://www.fass.se/LIF/home/index.jsp (accessed 22.07.11). 


\section{Supplementary Materials}

\section{Oxidation of pharmaceuticals by chlorine dioxide in biologically treated wastewater}

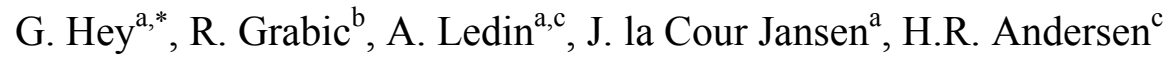

${ }^{a}$ Water and Environmental Engineering, Department of Chemical Engineering, Lund

University, P.O. Box 124, SE-221 00 Lund, Sweden

${ }^{\mathrm{b}}$ Department of Chemistry, Umeå University, SE-901 87 Umeå, Sweden

${ }^{\mathrm{c}}$ Department of Environmental Engineering, Technical University of Denmark,

Miljøvej, Building 113, DK-2800 Kongens Lyngby, Denmark

*Corresponding author: Gerly Hey, Phone: +46 46222 8998; fax: +46 462224526

Email: gerly.moradas@chemeng.lth.se

Table S1

List of suppliers for APIs and the corresponding internal standards used for quantification.

\begin{tabular}{|c|c|c|c|}
\hline APIs & Supplier & Internal standards & Supplier \\
\hline Alfuzosin & Sigma-Aldrich (Steinheim, Germany) & ${ }^{13} \mathrm{C}^{2} \mathrm{H}_{3}$ - Tramadol & $\begin{array}{l}\text { Cambridge Isotope Laboratories (Andover, MA, } \\
\text { USA) }\end{array}$ \\
\hline Alprazolam & Sigma-Aldrich (Steinheim, Germany) & ${ }^{13} \mathrm{C}^{2} \mathrm{H}_{3}$ - Tramadol & $\begin{array}{l}\text { Cambridge Isotope Laboratories (Andover, MA, } \\
\text { USA) }\end{array}$ \\
\hline Amitryptiline & Sigma-Aldrich (Steinheim, Germany) & ${ }^{2} \mathrm{H}_{6}$ - Amitriptyline & $\begin{array}{l}\text { Cambridge Isotope Laboratories (Andover, MA, } \\
\text { USA) }\end{array}$ \\
\hline Atracurium & Sigma-Aldrich (Steinheim, Germany) & ${ }^{13} \mathrm{C}^{2} \mathrm{H}_{3}$ - Tramadol & $\begin{array}{l}\text { Cambridge Isotope Laboratories (Andover, MA, } \\
\text { USA) }\end{array}$ \\
\hline Beclomethasone & Sigma-Aldrich (Steinheim, Germany) & ${ }^{2} \mathrm{H}_{5}$ - Oxazepam & Sigma-Aldrich (Steinheim, Germany) \\
\hline Bezafibrate & Sigma-Aldrich (Steinheim, Germany) & ${ }^{2} \mathrm{H}_{5}$ - Oxazepam & Sigma-Aldrich (Steinheim, Germany) \\
\hline Biperiden & Sigma-Aldrich (Steinheim, Germany) & ${ }^{2} \mathrm{H}_{6}$ - Amitriptyline & $\begin{array}{l}\text { Cambridge Isotope Laboratories (Andover, MA, } \\
\text { USA) }\end{array}$ \\
\hline Bisoprolol & Sigma-Aldrich (Steinheim, Germany) & ${ }^{13} \mathrm{C}^{2} \mathrm{H}_{3}$ - Tramadol & $\begin{array}{l}\text { Cambridge Isotope Laboratories (Andover, MA, } \\
\text { USA) }\end{array}$ \\
\hline Budesonide & Sigma-Aldrich (Steinheim, Germany) & ${ }^{2} \mathrm{H}_{5}$ - Fluoxetine & $\begin{array}{l}\text { Cambridge Isotope Laboratories (Andover, MA, } \\
\text { USA) }\end{array}$ \\
\hline Buprenorphine & Sigma-Aldrich (Steinheim, Germany) & ${ }^{13} \mathrm{C}^{2} \mathrm{H}_{3}$ - Tramadol & $\begin{array}{l}\text { Cambridge Isotope Laboratories (Andover, MA, } \\
\text { USA) }\end{array}$ \\
\hline Bupropion & Sigma-Aldrich (Steinheim, Germany) & ${ }^{13} \mathrm{C}^{2} \mathrm{H}_{3}$ - Tramadol & $\begin{array}{l}\text { Cambridge Isotope Laboratories (Andover, MA, } \\
\text { USA) }\end{array}$ \\
\hline Carbamazepine & Sigma-Aldrich (Steinheim, Germany) & ${ }^{2} \mathrm{H}_{10}$ - Carbamazepine & $\begin{array}{l}\text { Cambridge Isotope Laboratories (Andover, MA, } \\
\text { USA) }\end{array}$ \\
\hline Cilazapril & LGC Standards (Middlesex, UK) & ${ }^{13} \mathrm{C}^{2} \mathrm{H}_{3}$ - Tramadol & $\begin{array}{l}\text { Cambridge Isotope Laboratories (Andover, MA, } \\
\text { USA) }\end{array}$ \\
\hline Ciprofloxacin & Sigma-Aldrich (Steinheim, Germany) & ${ }^{13} \mathrm{C}_{3}{ }^{15} \mathrm{~N}$ - Ciprofloxacin & $\begin{array}{l}\text { Cambridge Isotope Laboratories (Andover, MA, } \\
\text { USA) }\end{array}$ \\
\hline Citalopram & Sigma-Aldrich (Steinheim, Germany) & ${ }^{13} \mathrm{C}^{2} \mathrm{H}_{3}$ - Tramadol & $\begin{array}{l}\text { Cambridge Isotope Laboratories (Andover, MA, } \\
\text { USA) }\end{array}$ \\
\hline Clindamycine & Sigma-Aldrich (Steinheim, Germany) & ${ }^{13} \mathrm{C}^{2} \mathrm{H}_{3}$ - Tramadol & $\begin{array}{l}\text { Cambridge Isotope Laboratories (Andover, MA, } \\
\text { USA) }\end{array}$ \\
\hline Clonazepam & Sigma-Aldrich (Steinheim, Germany) & ${ }^{13} \mathrm{C}^{2} \mathrm{H}_{3}$ - Tramadol & $\begin{array}{l}\text { Cambridge Isotope Laboratories (Andover, MA, } \\
\text { USA) }\end{array}$ \\
\hline Codeine & Sigma-Aldrich (Steinheim, Germany) & ${ }^{13} \mathrm{C}^{2} \mathrm{H}_{3}$ - Tramadol & $\begin{array}{l}\text { Cambridge Isotope Laboratories (Andover, MA, } \\
\text { USA) }\end{array}$ \\
\hline Cyproheptadine & Sigma-Aldrich (Steinheim, Germany) & ${ }^{13} \mathrm{C}^{2} \mathrm{H}_{3}$ - Tramadol & $\begin{array}{l}\text { Cambridge Isotope Laboratories (Andover, MA, } \\
\text { USA) }\end{array}$ \\
\hline
\end{tabular}




\begin{tabular}{|c|c|c|c|}
\hline Desloratidine & Sigma-Aldrich (Steinheim, Germany) & ${ }^{2} \mathrm{H}_{4}$ - Risperidone & Sigma-Aldrich (Steinheim, Germany) \\
\hline Diclofenac & Sigma-Aldrich (Steinheim, Germany) & ${ }^{13} \mathrm{C}^{2} \mathrm{H}_{3}$ - Tramadol & $\begin{array}{l}\text { Cambridge Isotope Laboratories (Andover, MA, } \\
\text { USA) }\end{array}$ \\
\hline Dicycloverin & LGC Standards (Middlesex, UK) & ${ }^{2} \mathrm{H}_{5}-$ Oxazepam & Sigma-Aldrich (Steinheim, Germany) \\
\hline Diltiazem & Sigma-Aldrich (Steinheim, Germany) & ${ }^{13} \mathrm{C}^{2} \mathrm{H}_{3}$ - Tramadol & $\begin{array}{l}\text { Cambridge Isotope Laboratories (Andover, MA, } \\
\text { USA) }\end{array}$ \\
\hline Diphenhydramine & Sigma-Aldrich (Steinheim, Germany) & ${ }^{13} \mathrm{C}^{2} \mathrm{H}_{3}$ - Tramadol & $\begin{array}{l}\text { Cambridge Isotope Laboratories (Andover, MA, } \\
\text { USA) }\end{array}$ \\
\hline Dipyridamole & Sigma-Aldrich (Steinheim, Germany) & ${ }^{13} \mathrm{C}^{2} \mathrm{H}_{3}$ - Tramadol & $\begin{array}{l}\text { Cambridge Isotope Laboratories (Andover, MA, } \\
\text { USA) }\end{array}$ \\
\hline Eprosartan & CHEMOS GmbH (Regenstauf, Germany) & ${ }^{2} \mathrm{H}_{10}$ - Carbamazepine & $\begin{array}{l}\text { Cambridge Isotope Laboratories (Andover, MA, } \\
\text { USA) }\end{array}$ \\
\hline Estriol & Sigma-Aldrich (Steinheim, Germany) & ${ }^{13} \mathrm{C}_{2}$. Ethinyl estradiol & $\begin{array}{l}\text { Cambridge Isotope Laboratories (Andover, MA, } \\
\text { USA) }\end{array}$ \\
\hline Estrone & Sigma-Aldrich (Steinheim, Germany) & ${ }^{13} \mathrm{C}_{2}$ - Ethinyl estradiol & $\begin{array}{l}\text { Cambridge Isotope Laboratories (Andover, MA, } \\
\text { USA) }\end{array}$ \\
\hline Ethinyl estradiol & Sigma-Aldrich (Steinheim, Germany) & ${ }^{13} \mathrm{C}_{2}$ - Ethinyl estradiol & $\begin{array}{l}\text { Cambridge Isotope Laboratories (Andover, MA, } \\
\text { USA) }\end{array}$ \\
\hline Fexofenadine & Sigma-Aldrich (Steinheim, Germany) & ${ }^{2} \mathrm{H}_{6}$ - Amitriptyline & $\begin{array}{l}\text { Cambridge Isotope Laboratories (Andover, MA, } \\
\text { USA) }\end{array}$ \\
\hline Finasteride & Sigma-Aldrich (Steinheim, Germany) & ${ }^{2} \mathrm{H}_{5}$ - Oxazepam & Sigma-Aldrich (Steinheim, Germany) \\
\hline Fluconazole & Sigma-Aldrich (Steinheim, Germany) & ${ }^{13} \mathrm{C}_{3}$ - Trimethoprim & $\begin{array}{l}\text { Cambridge Isotope Laboratories (Andover, MA, } \\
\text { USA) }\end{array}$ \\
\hline Fluoxetine & Sigma-Aldrich (Steinheim, Germany) & ${ }^{2} \mathrm{H}_{5}$ - Fluoxetine & $\begin{array}{l}\text { Cambridge Isotope Laboratories (Andover, MA, } \\
\text { USA) }\end{array}$ \\
\hline Flutamide & Sigma-Aldrich (Steinheim, Germany) & ${ }^{2} \mathrm{H}_{6}$ - Amitriptyline & $\begin{array}{l}\text { Cambridge Isotope Laboratories (Andover, MA, } \\
\text { USA) }\end{array}$ \\
\hline Hydroxyzine & Sigma-Aldrich (Steinheim, Germany) & ${ }^{2} \mathrm{H}_{6}$ - Amitriptyline & $\begin{array}{l}\text { Cambridge Isotope Laboratories (Andover, MA, } \\
\text { USA) }\end{array}$ \\
\hline Irbesartan & CHEMOS GmbH (Regenstauf, Germany) & ${ }^{2} \mathrm{H}_{6}$ - Amitriptyline & $\begin{array}{l}\text { Cambridge Isotope Laboratories (Andover, MA, } \\
\text { USA) }\end{array}$ \\
\hline Maprotiline & Sigma-Aldrich (Steinheim, Germany) & ${ }^{2} \mathrm{H}_{6}$ - Amitriptyline & $\begin{array}{l}\text { Cambridge Isotope Laboratories (Andover, MA, } \\
\text { USA) }\end{array}$ \\
\hline Memantine & Sigma-Aldrich (Steinheim, Germany) & ${ }^{13} \mathrm{C}^{2} \mathrm{H}_{3}$ - Tramadol & $\begin{array}{l}\text { Cambridge Isotope Laboratories (Andover, MA, } \\
\text { USA) }\end{array}$ \\
\hline Metoprolol & Sigma-Aldrich (Steinheim, Germany) & ${ }^{13} \mathrm{C}^{2} \mathrm{H}_{3}$ - Tramadol & $\begin{array}{l}\text { Cambridge Isotope Laboratories (Andover, MA, } \\
\text { USA) }\end{array}$ \\
\hline Mianserin & Sigma-Aldrich (Steinheim, Germany) & ${ }^{13} \mathrm{C}^{2} \mathrm{H}_{3}$ - Tramadol & $\begin{array}{l}\text { Cambridge Isotope Laboratories (Andover, MA, } \\
\text { USA) }\end{array}$ \\
\hline Mirtazapine & Sigma-Aldrich (Steinheim, Germany) & ${ }^{13} \mathrm{C}^{2} \mathrm{H}_{3}$ - Tramadol & $\begin{array}{l}\text { Cambridge Isotope Laboratories (Andover, MA, } \\
\text { USA) }\end{array}$ \\
\hline Naloxone & Sigma-Aldrich (Steinheim, Germany) & ${ }^{13} \mathrm{C}^{2} \mathrm{H}_{3}$ - Tramadol & $\begin{array}{l}\text { Cambridge Isotope Laboratories (Andover, MA, } \\
\text { USA) }\end{array}$ \\
\hline Orphenadrine & LGC Standards (Middlesex, UK) & ${ }^{2} \mathrm{H}_{6}$ - Amitriptyline & $\begin{array}{l}\text { Cambridge Isotope Laboratories (Andover, MA, } \\
\text { USA) }\end{array}$ \\
\hline Paroxetine & Sigma-Aldrich (Steinheim, Germany) & ${ }^{2} \mathrm{H}_{6}$ - Amitriptyline & $\begin{array}{l}\text { Cambridge Isotope Laboratories (Andover, MA, } \\
\text { USA) }\end{array}$ \\
\hline Pizotifen & LGC Standards (Middlesex, UK) & ${ }^{2} \mathrm{H}_{6}$ - Amitriptyline & $\begin{array}{l}\text { Cambridge Isotope Laboratories (Andover, MA, } \\
\text { USA) }\end{array}$ \\
\hline Promethazine & Sigma-Aldrich (Steinheim, Germany) & ${ }^{2} \mathrm{H}_{6}$ - Amitriptyline & $\begin{array}{l}\text { Cambridge Isotope Laboratories (Andover, MA, } \\
\text { USA) }\end{array}$ \\
\hline Repaglinide & Sigma-Aldrich (Steinheim, Germany) & ${ }^{2} \mathrm{H}_{6}$ - Amitriptyline & $\begin{array}{l}\text { Cambridge Isotope Laboratories (Andover, MA, } \\
\text { USA) }\end{array}$ \\
\hline Risperidone & LGC Standards (Middlesex, UK) & ${ }^{2} \mathrm{H}_{4}$ - Risperidone & Sigma-Aldrich (Steinheim, Germany) \\
\hline Sotalol & Sigma-Aldrich (Steinheim, Germany) & ${ }^{13} \mathrm{C}^{2} \mathrm{H}_{3}$ - Tramadol & $\begin{array}{l}\text { Cambridge Isotope Laboratories (Andover, MA, } \\
\text { USA) }\end{array}$ \\
\hline Sulfamethoxazole & Sigma-Aldrich (Steinheim, Germany) & ${ }^{13} \mathrm{C}_{6}$ - Sulfamethoxazole & $\begin{array}{l}\text { Cambridge Isotope Laboratories (Andover, MA, } \\
\text { USA) }\end{array}$ \\
\hline Telmisartan & Sigma-Aldrich (Steinheim, Germany) & ${ }^{2} \mathrm{H}_{6}$ - Amitriptyline & $\begin{array}{l}\text { Cambridge Isotope Laboratories (Andover, MA, } \\
\text { USA) }\end{array}$ \\
\hline Tramadol & Sigma-Aldrich (Steinheim, Germany) & ${ }^{13} \mathrm{C}^{2} \mathrm{H}_{3}$ - Tramadol & $\begin{array}{l}\text { Cambridge Isotope Laboratories (Andover, MA, } \\
\text { USA) }\end{array}$ \\
\hline Trihexyphenidyl & Sigma-Aldrich (Steinheim, Germany) & ${ }^{2} \mathrm{H}_{6}$ - Amitriptyline & $\begin{array}{l}\text { Cambridge Isotope Laboratories (Andover, MA, } \\
\text { USA) }\end{array}$ \\
\hline Trimethoprim & Sigma-Aldrich (Steinheim, Germany) & ${ }^{13} \mathrm{C}_{3}$ - Trimethoprim & $\begin{array}{l}\text { Cambridge Isotope Laboratories (Andover, MA, } \\
\text { USA) }\end{array}$ \\
\hline Venlafaxine & Sigma-Aldrich (Steinheim, Germany) & ${ }^{13} \mathrm{C}^{2} \mathrm{H}_{3}$ - Tramadol & $\begin{array}{l}\text { Cambridge Isotope Laboratories (Andover, MA, } \\
\text { USA) }\end{array}$ \\
\hline Zolpidem & LGC Standards (Middlesex, UK) & ${ }^{13} \mathrm{C}^{2} \mathrm{H}_{3}$ - Tramadol & $\begin{array}{l}\text { Cambridge Isotope Laboratories (Andover, MA, } \\
\text { USA) }\end{array}$ \\
\hline
\end{tabular}


Table S2

Ionization mode, recoveries and relative standard deviation (RSD) of the APIs

\begin{tabular}{|c|c|c|c|}
\hline API & Ionization mode & Recovery (average of triplicate) & RSD \\
\hline & & $\%$ & $\%$ \\
\hline Alfuzosin & HESI & 111 & 6.2 \\
\hline Alprazolam & HESI & 67.8 & 2.8 \\
\hline Amitryptiline & HESI & 83.3 & 7.5 \\
\hline Atracurium & HESI & 85.8 & 7.2 \\
\hline Beclomethasone & HESI & 25.2 & 12.9 \\
\hline Bezafibrate & HESI & 126 & 1.1 \\
\hline Biperiden & HESI & 106 & 8.4 \\
\hline Bisoprolol & HESI & 83.1 & 5.1 \\
\hline Budesonide & HESI & 111 & 9.5 \\
\hline Buprenorphine & HESI & 88.6 & 5.3 \\
\hline Bupropion & HESI & 96.3 & 4.7 \\
\hline Carbamazepine & HESI & 101 & 15.1 \\
\hline Cilazapril & HESI & 143 & 5.9 \\
\hline Ciprofloxacin & HESI & 86.3 & 4.1 \\
\hline Citalopram & HESI & 83.6 & 8.5 \\
\hline Clindamycine & HESI & 76.7 & 9.4 \\
\hline Clonazepam & HESI & 67.6 & 5.8 \\
\hline Codeine & HESI & 86.7 & 24.0 \\
\hline Cyproheptadine & HESI & 80.0 & 2.4 \\
\hline Desloratidine & HESI & 57.1 & 4.0 \\
\hline Diclofenac & HESI & 42.1 & 4.4 \\
\hline Dicycloverin & HESI & 84.1 & 7.7 \\
\hline Diltiazem & HESI & 107 & 3.8 \\
\hline Diphenhydramine & HESI & 99.0 & 15.1 \\
\hline Dipyridamole & HESI & 72.0 & 7.6 \\
\hline Eprosartan & HESI & 62.3 & 4.3 \\
\hline Estriol & APCI/APPI & 129 & 24.7 \\
\hline Estrone & APCI/APPI & 134 & 19.9 \\
\hline Ethinyl estradiol & APCI/APPI & 85.7 & 4.1 \\
\hline Fexofenadine & HESI & 81.1 & 7.1 \\
\hline Finasteride & HESI & 80.0 & 5.1 \\
\hline Fluconazole & HESI & 89.8 & 12.9 \\
\hline Fluoxetine & HESI & 97.0 & 11.4 \\
\hline Flutamide & HESI & 91.8 & 3.9 \\
\hline Hydroxyzine & HESI & 94.5 & 14.2 \\
\hline Irbesartan & HESI & 109 & 2.6 \\
\hline Maprotiline & HESI & 84.1 & 7.4 \\
\hline Memantine & HESI & 85.7 & 7.7 \\
\hline Metoprolol & HESI & 82.9 & 1.3 \\
\hline Mianserin & HESI & 81.0 & 12.5 \\
\hline Mirtazapine & HESI & 90.3 & 17.3 \\
\hline Naloxone & HESI & 75.8 & 30.2 \\
\hline Orphenadrine & HESI & 94.7 & 11.2 \\
\hline Paroxetine & HESI & 62.7 & 5.5 \\
\hline Pizotifen & HESI & 90.8 & 5.3 \\
\hline Promethazine & HESI & 108 & 6.7 \\
\hline Repaglinide & HESI & 93.4 & 8.6 \\
\hline Risperidone & HESI & 101 & 2.4 \\
\hline
\end{tabular}




\begin{tabular}{lccc} 
Sotalol & HESI & 125 & 14.7 \\
Sulfamethoxazole & HESI & 97.3 & 4.3 \\
Telmisartan & HESI & 106 & 15.2 \\
Tramadol & HESI & 129 & 6.3 \\
Trihexyphenidyl & HESI & 124 & 12.2 \\
Trimethoprim & HESI & 109 & 10.7 \\
Venlafaxine & HESI & 96.2 & 7.8 \\
Zolpidem & HESI & 94.3 & 4,4 \\
& & & \\
Median & & 91 & 7.3 \\
Min & & 25 & 1.1 \\
Max & & 143 & 30 \\
\hline
\end{tabular}

Note:

Recovery experiment at $1000 \mathrm{ng} / \mathrm{L}(\mathrm{n}=3)$. 3 APIs has recovery of $<60 \%$; 1 API has recovery of $>130 \%$ 